\title{
Changing Phenology of Potato and of the Treatment for its Major Pest (Colorado Potato Beetle) - A Long-term Analysis
}

\author{
Piotr Tryjanowski $^{1}$ (D) Tim H. Sparks ${ }^{1,2}$ - Andrzej Blecharczyk ${ }^{3}$. \\ Irena Malecka-Jankowiak ${ }^{3}$ - Stanislaw Switek ${ }^{1}$. Zuzanna Sawinska ${ }^{3}$
}

Published online: 3 November 2017

(C) The Author(s) 2017. This article is an open access publication

\begin{abstract}
Potato Solanum tuberosum is one of the world's four most important crops. Its cultivation is steadily increasing in response to the need to feed a growing world population. The yield of potato is influenced inter alia by both climate and pests. The main defoliator pest of potato is Colorado potato beetle Leptinotarsa decemlineata. Using data from a longterm experiment (1958-2013) in western Poland, we show that increasing temperature has affected the trophic relationship between potato and Colorado potato beetle. The planting, leafing, flowering and harvest dates for potato were advanced, after controlling for different cultivars, by 2.00 days, 3.04 days, 3.80 days and 3.42 days respectively for every $1{ }^{\circ} \mathrm{C}$ increase in temperature. In contrast, first treatment against Colorado potato beetle advanced by 4.66 days for every $1{ }^{\circ} \mathrm{C}$ increase in temperature, and, furthermore, the number of treatments against the beetle increased by 0.204 per $1{ }^{\circ} \mathrm{C}$ increase in temperature. This suggests that the beetle responds faster to increasing temperature than the plant does, but both parts of the system are probably greatly modified by farming practices.
\end{abstract}

Resumen La papa, Solanum tuberosum, es uno de los cuatro cultivos más importantes del mundo. Su cultivo está aumentando de manera estable en respuesta a la necesidad

Piotr Tryjanowski

piotr.tryjanowski@gmail.com

1 Institute of Zoology, Poznań University of Life Sciences, Wojska Polskiego 71C, 60-625 Poznań, Poland

2 Faculty of Engineering, Environment and Computing, Coventry University, Coventry CV1 5FB, UK

3 Department of Agronomy, Poznań University of Life Sciences, Dojazd 11, 60-632 Poznań, Poland de alimentación a una población mundial en crecimiento. El rendimiento de la papa es influenciado, inter alia, por ambos, clima y plagas. La principal plaga defoliadora de la papa es el escarabajo de Colorado Leptinotarsa decemlineata. Utilizando datos de un experimento a largo plazo (19582013) en el oeste de Polonia, mostramos que el aumento de temperatura ha afectado la relación trófica entre la papa y el escarabajo de Colorado. Se adelantaron las fechas de siembra, fase vegetativa, la floración y cosecha de la papa, después del control para diferentes variedades, por 2.00, 3.04, 3.80, y 3.42 días, respectivamente, por cada incremento de $1{ }^{\circ} \mathrm{C}$ de temperatura. En contraste, el primer tratamiento contra el escarabajo de Colorado adelantó 4.66 días por cada $1{ }^{\circ} \mathrm{C}$ de aumento en la temperatura, y aún más, el número de tratamientos contra el escarabajo aumentó 0.204 por $1{ }^{\circ} \mathrm{C}$ de aumento en la temperatura. Esto sugiere que el escarabajo responde más rápido al aumento de temperatura que la planta, pero ambas partes del sistema son probablemente mayormente modificadas por las prácticas culturales.

Keywords Climate $\cdot$ Phenology $\cdot$ Pests $\cdot$ Varietas $\cdot$ Harvest . Agricultural practices $\cdot$ Long-term experiment

\section{Introduction}

Phenological changes have been observed in many groups of wild and ornamental plants (herbs, grasses, trees) as well as in agricultural crops, and have been reported from different latitudinal and climatic zones (Parmesan and Yohe 2003; Richardson et al. 2013). It is well known that responses of individual organisms to changes in ambient temperature will affect interactions with other organisms in the same or different trophic levels (Walther et al. 2002), which in turn can impact the ecology and (co-)evolution of pests and their host plants 
(Harrington et al. 1999). However, to understand interactions between herbivorous insects and plants, detailed knowledge from long-term series are necessary (Kort 1990; Sparks et al. 2011; Richardson et al. 2013) and is crucial to successful management of farming systems against pests under future climatic changes (Porter et al. 1991). Increasing temperatures have been associated recently with a shorter development period, a higher number of generations, and a faster reproduction rate in many herbivorous pests (Gregory et al. 2009).

Climate change may have direct impacts on yields. Increasing crop yield in Europe in the last 50 years is largely attributed to developments in agronomy, introduction of new cultivars and only modestly to climate change (Haverkort and Verhagen 2008). However, in some regions yields will be reduced due to lower rainfall during the summer (Supit et al. 2012), and a longer growing season and a higher concentration of $\mathrm{CO}_{2}$ is likely, but the crop will require irrigation. Climate change may also have indirect impacts on yields, due to alterations to pest-crop dynamics. Insect development time is regulated in part by temperature, thus at higher temperatures, more generations may be produced each year. Moreover, mild winters or winters with snow cover may enhance overwinter survival (Hiiesaar et al. 2016).

For potato, climate change may indirectly impact yield by altering interactions between potato Solanum tuberosum and its insect pests, in particular, the Colorado potato beetle Leptinotarsa decemlineata. Colorado potato beetle is one of the most destructive arthropod pests affecting Solanaceous crop production (Alyokhin et al. 2008). Reproductively, Colorado potato beetle has the ability to be extremely prolific and fecund from both overwintered and recently emerged adults (Peferoen et al. 1981). The larvae progress through a series of four instars over a period of 10 to 20 days, depending on host plant quality, environmental conditions (Dolezal et al. 2007) and location (Pulatov et al. 2016). In a typical summer, Colorado potato beetle populations undergo two successive full generations in most parts of Europe (Kung et al. 1992; Pulatov et al. 2016).

Phenology research can provide information on how plants respond to a changing climate. Worldwide there are many phenological data but the main problem is interpretation of the results in a regional and ecological context. While there are many papers showing how climate change is affecting phenology, a realization that species respond at different rates and that climate change varies regionally is necessary (Schwartz 1999).

The aim of our study is (1) to investigate how changes in ambient temperature may be driving the phenology of the potato crop and (2), to determine how such temperature changes may be mediating the phenological matching of the potato crop and its primary insect pest, the Colorado potato beetle. Finally, we discuss the implications of phenological changes to both the potato plant and its primary pest to potato production, and how growers may respond to such changes.

\section{Materials and Methods}

\section{Study Area}

Our study is based on a long-term experiment established in 1957. The original aim was to demonstrate how fertilizers affected soil fertility under continuous cropping. The experiment was at the Brody Experimental Station $\left(52^{\circ} 26^{\prime} \mathrm{N}, 16^{\circ} 18^{\prime}\right.$ E) of the Agronomy Department of Poznań University of Life Sciences, located $50 \mathrm{~km}$ west of Poznań in the Wielkopolska region of Poland. It was established as a randomized block design of four replicates on a podzolic soil. The soil texture was sandy loam with underlying loams. At the start of the experiment the soil had a $\mathrm{pH}$ of about $6.0(\mathrm{pH}$ in mol $\mathrm{KCl}$ $\mathrm{dm}^{-3}$ ), a very high phosphorus content, average magnesium and potassium content, and contained about $7 \mathrm{~g} \mathrm{~kg}^{-1}$ of organic carbon. Annual precipitation averaged $595 \mathrm{~mm}$ during the study period (range $288-840 \mathrm{~mm}$ ). Potato was grown continuously since 1958 on the same plots. This is one of the oldest experiments in Poland, and one of only three designed in a similar way in Europe, based on a valid statistical design. More details on the study area with information on soil fertility are provided in Blecharczyk et al. $(2008,2016)$ and Szajdak et al. (2004).

\section{Potato Data}

During the 56 years of records (1958-2013) six different cultivars of potato have been grown (Table 1) both as part of a rotation and as a continuously cropped monoculture. Phenological observations on potato were made using the $\mathrm{BBCH}$ (Biologische Bundesanstalt, Bundessortenamt und Chemische Industrie) scale (Hack et al. 1993). The BBCH scales are well known worldwide and are used for research, agronomy and in phenology. In this study we recorded the following development stages of potato: planting date (BBCH 02); first leaves beginning to extend (BBCH 10); first open flowers (BBCH 60); harvest (BBCH 91-97), and yields from both types of cultivation were also recorded. All dates were converted to days of the year (DOY; $1=$ Jan 1st etc.) prior to analysis.

Traditionally the main crop is harvested when the vines and tubers are mature. From 1958 to 1965 a potato spinner was used during harvest, and subsequently an elevator potato digger. Potatoes were then gathered by hand, placed into containers and transported from the field.

\section{Colorado Potato Beetle Data}

From 1969 the number of treatments, using insecticides approved for use in Poland at that date, against Colorado potato beetle was recorded. In this study the timing and number of beetles was not directly recorded and farmers' decisions on 
Table 1 A summary of mean \pm SE yield and cultivation phenology for potato crops at Brody, Poland 1958-2013

\begin{tabular}{|c|c|c|c|c|c|c|c|c|}
\hline Cultivar & Period & $n$ & $\begin{array}{l}\text { Rotation } \\
\text { Yield } \\
\text { t/ha }\end{array}$ & $\begin{array}{l}\text { Mono- culture } \\
\text { Yield } \\
\text { t/ha }\end{array}$ & $\begin{array}{l}\text { planting } \\
\text { date } \\
\text { DOY }\end{array}$ & $\begin{array}{l}\text { leafing } \\
\text { date } \\
\text { DOY }\end{array}$ & $\begin{array}{l}\text { flowering } \\
\text { date } \\
\text { DOY }\end{array}$ & $\begin{array}{l}\text { harvest } \\
\text { date } \\
\text { DOY }\end{array}$ \\
\hline Lenino & $1958-64$ & 7 & $24.6 \pm 2.5$ & $18.8 \pm 1.7$ & $127 \pm 2$ & $148 \pm 2$ & $183 \pm 2$ & $273 \pm 4$ \\
\hline Uran & $1965-85$ & 21 & $30.7 \pm 1.8$ & $13.3 \pm 1.3$ & $111 \pm 2$ & $141 \pm 2$ & $179 \pm 2$ & $259 \pm 1$ \\
\hline Tarpan & $1986-95$ & 10 & $25.8 \pm 2.6$ & $16.3 \pm 1.9$ & $112 \pm 3$ & $139 \pm 3$ & $178 \pm 2$ & $270 \pm 3$ \\
\hline Ania & 1996-98 & 3 & $42.3 \pm 3.7$ & $23.2 \pm 3.8$ & $113 \pm 4$ & $142 \pm 2$ & $182 \pm 6$ & $275 \pm 4$ \\
\hline Sante & 1999-2009 & 11 & $28.4 \pm 2.2$ & $13.8 \pm 1.7$ & $109 \pm 2$ & $139 \pm 2$ & $173 \pm 2$ & $253 \pm 2$ \\
\hline Wineta & $2010-13$ & 4 & $28.5 \pm 2.9$ & $13.2 \pm 1.9$ & $105 \pm 3$ & $136 \pm 3$ & $173 \pm 2$ & $252 \pm 3$ \\
\hline \multirow[t]{6}{*}{ All } & $1958-2013$ & 56 & $29.1 \pm 1.1$ & $15.2 \pm 0.8$ & $112 \pm 1$ & $141 \pm 1$ & $178 \pm 1$ & $262 \pm 1$ \\
\hline & ANOVA & $\mathrm{p}$ & 0.024 & 0.042 & $<0.001$ & 0.093 & 0.055 & $<0.001$ \\
\hline & \multirow[t]{2}{*}{ Regression } & $\mathrm{R}^{2}$ & $0.1 \%$ & $2.2 \%$ & $23.2 \%$ & $11.9 \%$ & $11.1 \%$ & $13.6 \%$ \\
\hline & & $\mathrm{p}$ & 0.800 & 0.274 & $<0.001$ & 0.009 & 0.012 & 0.005 \\
\hline & \multirow[t]{2}{*}{ residual trend } & $\mathrm{R}^{2}$ & $24.0 \%$ & $30.3 \%$ & $42.5 \%$ & $18.4 \%$ & $19.1 \%$ & $53.1 \%$ \\
\hline & & $\mathrm{p}$ & 0.295 & 0.010 & 0.119 & 0.315 & 0.777 & 0.516 \\
\hline
\end{tabular}

The ANOVA $p$ value summarises differences between cultivars, the regression $p$ value summarises whether a long-term trend exists (ignoring cultivar changes), and the residual trend $p$ value summarises whether a long-term trend can be detected after controlling for cultivar effects

treatment applications were based on perceived negative impact on potato yield. The dates of the first and any subsequent treatments were recorded and converted to days of the year. The first treatment date is considered as a surrogate of early beetle activity.

\section{Temperature Data}

Mean monthly temperatures for 1959-2013 were obtained from the Brody Experimental Station's meteorological station and were recorded according to the World Meteorological Organisation guidelines. Data were not available for 1958.

\section{Analysis}

Mean potato yields and phenology were compared against cultivar to check for differences that could be attributed to the latter using one way ANOVA. One problem we have is that cultivar and time are confounded so it is difficult to separate cultivar effects from long-term trends, for example in temperature. For the same variables, linear regression on year was carried out to see if there were any long-term trends ignoring cultivar effect. We then regressed the same variables on cultivar and year to see if there were any residual trends through time once cultivar effects were controlled for. Trends in mean monthly temperature were identified using correlations with year. Responses of potato phenology to mean monthly temperature were examined using regression techniques before and after controlling for any potential confounding factors (e.g. cultivar) or confounding variables (e.g. planting date). Suitable months for temperature were identified by preliminary screening based on correlations. A similar approach was adopted for Colorado potato beetle treatment phenology but without controlling for cultivar or potato phenology. The number of Colorado potato beetle treatments was compared to mean monthly temperature data using Poisson regression.

\section{Results}

\section{Potato Yields}

There were significant differences between cultivars in both rotational and monoculture mean potato yields (Table 1). The yield of the latter is now typically about one half of that achieved under a crop rotation (Fig. 1). No trends in yields were detected (ignoring cultivar effects) but once cultivar effects had been incorporated a significant decline in monoculture yields was detected.

\section{Potato Phenology}

A significant advance over time was detected in all four phenology variables (Table 1, Fig. 2). However, differences between cultivars were only significant for planting and harvest date and were only marginal $(p<0.10)$ for leafing and flowering date. Long-term trends were not detected after cultivar effects had been controlled for. Please note that the mean planting date of the most recent cultivar (Wineta) was 15 days earlier than that of the original cultivar (Lenino), leafing date was 7 days earlier, flowering date 5 days earlier and harvest date 11 days earlier. 
Fig. 1 Trends in the difference between rotational and monoculture potato yields ( $\mathrm{Y}-$ axis) in the years 1958-2013 (Xaxis); all values are positive indicating consistently higher yields in the former

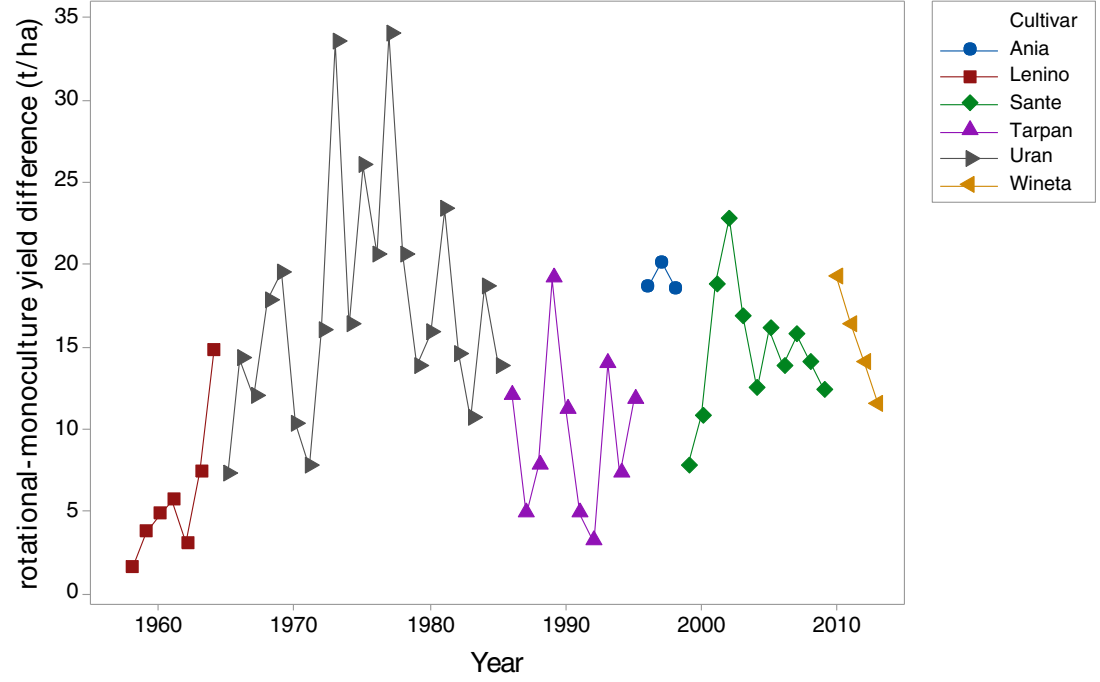

\section{Colorado Potato Beetle Treatment Phenology}

There was a significant advance in the first treatment for Colorado potato beetle $\left(-0.381 \pm 0.117\right.$ days year ${ }^{-1}$, $\left.\mathrm{R}^{2}=21.3 \%, p=0.002\right)$ but no significant change over time in the number of treatments (Poisson regression: $0.012 \pm 0.008$ treatments year ${ }^{-1}$, Deviance $\mathrm{R}^{2}=5.5 \%, p=0.121$; Fig. 3).

\section{Temperature Influences on Potato Phenology}

Planting date is arguably a direct human decision, but that decision will be influenced by the preceding and prevailing weather. Regressing planting date on mean January-March temperature produced a coefficient of $-2.16 \pm 0.43$ days ${ }^{\circ} \mathrm{C}^{-1}\left(\mathrm{R}^{2}=32.6 \%, p<0.001\right.$; Fig. 4), suggesting an advance of planting date by just over two days for every $1{ }^{\circ} \mathrm{C}$ increase in temperature between January and March (Fig. 1). In case planting date was influenced by cultivar choice the regression was repeated controlling for cultivar and produced a coefficient of similar magnitude $\left(-2.00 \pm 0.39\right.$ days ${ }^{\circ} \mathrm{C}^{-1}$, $\left.\mathrm{R}^{2}=57.6 \%, p<0.001\right)$.

Leafing date was regressed on mean March-May temperature to produce a coefficient of $-2.70 \pm 0.68$ days ${ }^{\circ} \mathrm{C}^{-1}$ $\left(\mathrm{R}^{2}=22.7 \%, p<0.001\right.$; Fig. 4). Controlling for cultivar

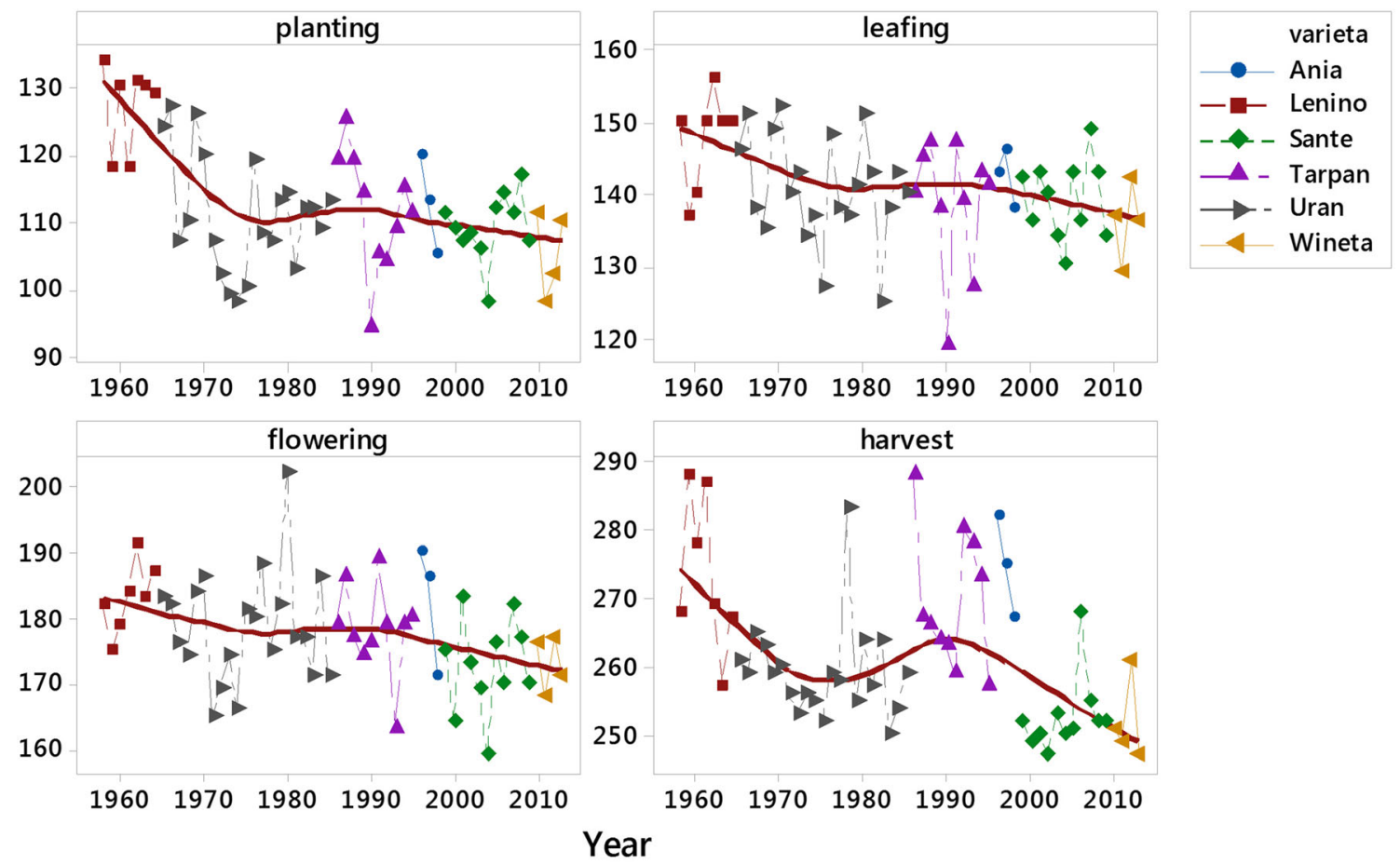

Fig. 2 Changes in potato phenological stages expressed as days after1st January (Y-axis) during the years 1958-2013 (X-axis). Single smoothed (lowess) lines have been superimposed 
Fig. 3 Changes in the first treatment date (day of the year after $1^{\text {st }}$ of January; Y-axis; left panel) and number of treatments (Y-axis; right panel) for Colorado potato beetle in the years 19692013 (X-axis). Smoothed (lowess) lines have been superimposed

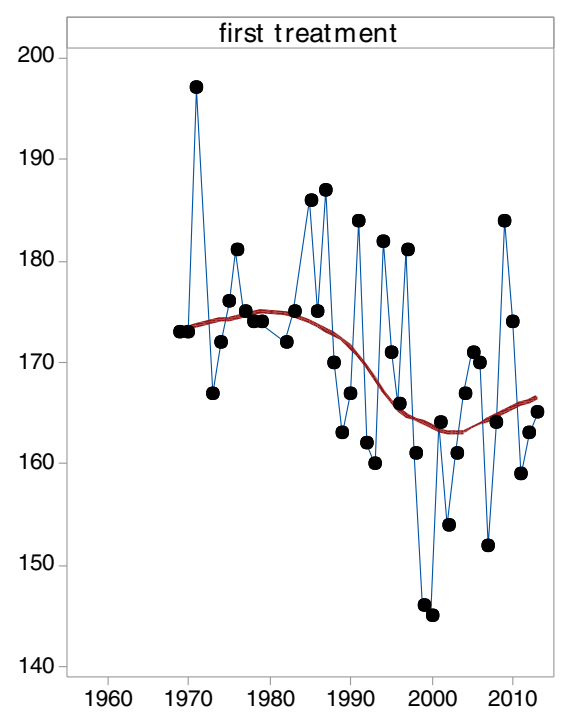

changed this to $-3.04 \pm 0.84$ days ${ }^{\circ} \mathrm{C}^{-1}\left(\mathrm{R}^{2}=32.7 \%\right.$, $p=0.001)$. After controlling for both cultivar and planting date the influence of temperature (May only) was $-1.34 \pm 0.55$ days ${ }^{\circ} \mathrm{C}^{-1}\left(\mathrm{R}^{2}=52.8 \%, p=0.019\right)$. Comparable regressions for flowering date produced coefficients of $-3.80 \pm 0.67$ days ${ }^{\circ} \mathrm{C}^{-1}\left(\mathrm{R}^{2}=37.7 \%, p<0.001\right.$; Fig. 4), $-3.82 \pm 0.85$ days ${ }^{\circ} \mathrm{C}^{-1}\left(\mathrm{R}^{2}=42.7 \%, p<0.001\right)$, and $-2.35 \pm 0.62$ days ${ }^{\circ} \mathrm{C}^{-1}\left(\mathrm{R}^{2}=49.2 \%, p<0.001\right)$ respectively. When regressed on Mean July-September dates, harvest date had a coefficient of $-3.42 \pm 1.13$ days ${ }^{\circ} \mathrm{C}^{-1}$ $\left(\mathrm{R}^{2}=14.8 \%, p=0.004\right.$; Fig. 4). This was not significant after controlling for cultivar and/or planting date.

\section{Temperature Influences on Colorado Potato Beetle Treatment Phenology and Severity}

The timing of the first Colorado potato beetle treatment on mean January-June temperatures produced a coefficient of
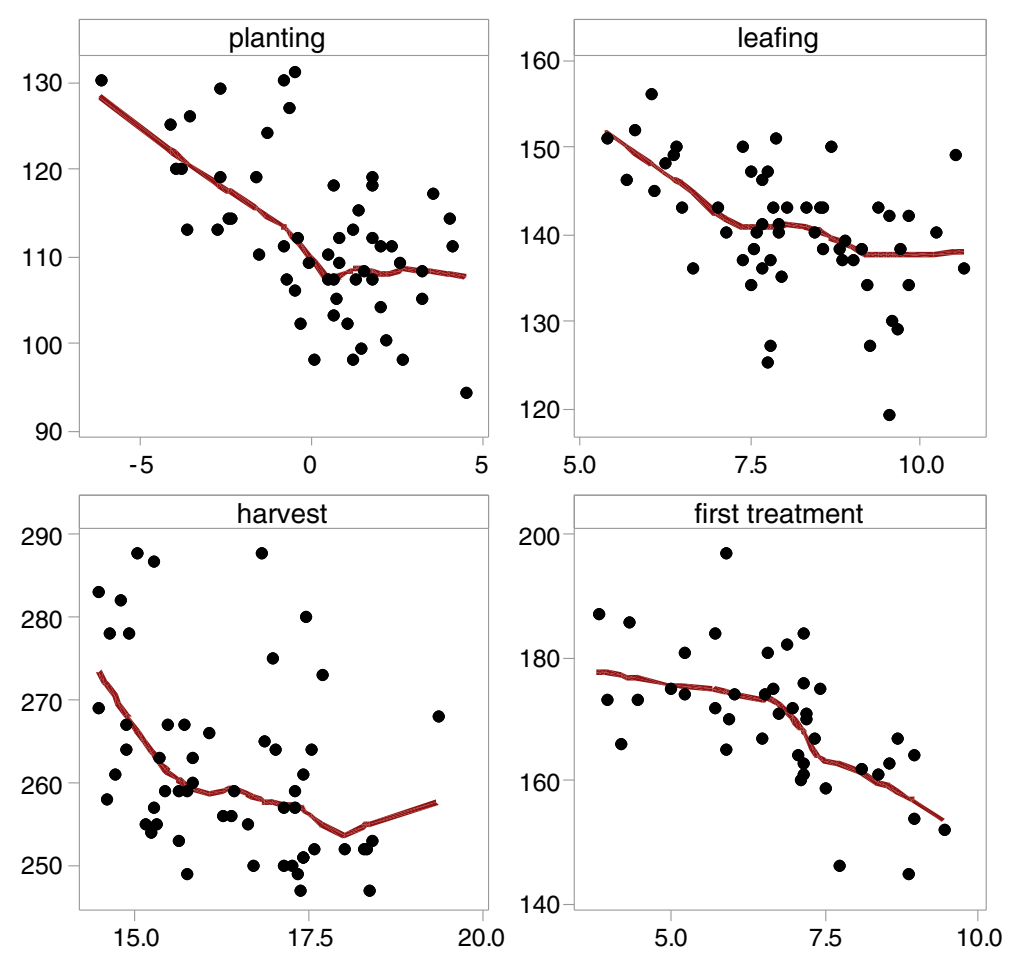
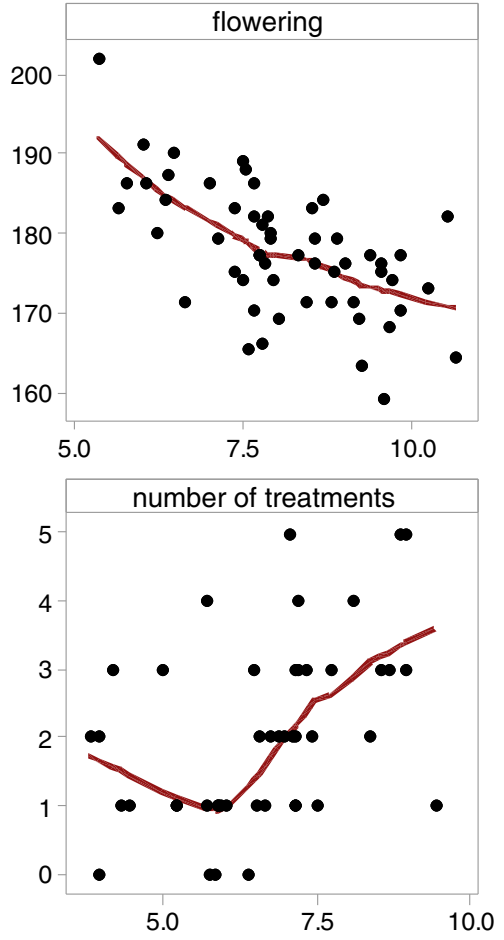

Fig. 4 Plot of planting date against mean January-March temperature, leafing date and flowering date both against mean March-May temperature, harvest date against mean July-September temperature, and date of first (Colorado potato beetle) treatment and number of treatments both against mean January-June temperature. All dates shown as day of the year (DOY on Y-axis), all temperatures in ${ }^{\circ} \mathrm{C}(\mathrm{X}$ axis). Single smoothed (lowess) lines have been superimposed 
$-4.66 \pm 0.93$ days ${ }^{\circ} \mathrm{C}^{-1}\left(\mathrm{R}^{2}=39.3 \%, p<0.001\right.$; Fig. 4). The effect of mean January-June temperature on the number of treatments was to increase the number of treatments by $0.204 \pm 0.074$ treatments ${ }^{\circ} \mathrm{C}^{-1}$ (Deviance $\mathrm{R}^{2}=17.6 \%$, $p=0.006$; Fig. 4). First Colorado potato beetle treatment timing was not significantly correlated with either first leafing date $(r=0.164, p=0.305)$ or flowering date $(r=0.240$, $p=0.131)$ suggesting no synchrony with potato phenology.

\section{Discussion}

During our analysis we detected changes in the phenology of both the host plant (potato) and the treatment for its pest species (Colorado potato beetle), and their interaction with local temperatures. The mean planting date advanced considerably, as confirmed elsewhere (Sacks et al. 2010). In our study the most recent cultivar had a mean planting date 15 days earlier than that of the original cultivar. Unfortunately we do not have data on a single cultivar of potato for the entire duration of the study because of changing commercial practices in which turnover in cultivars is common. Part of the role of the experimental research station was to provide topical agronomic advice to the local farmers, especially big state farms, and hence cultivars had to be changed. Not only is the climate changing, but also the agricultural calendar that dictates dates for execution of field work (Sparks et al. 2005, Estrella et al. 2007). However, for example in Germany, the change in management timing is not progressing as fast as the changing phenology of the plants (Menzel et al. 2006). The timing of spring sowing depends on the type of soil, preceding, prevailing and forecast weather conditions, as well as the judgement and custom of the farmer. In Finland the timing of planting potatoes has advanced in response to climate change; between 1965 and 1979 potato planting advanced 3.4 days decade ${ }^{-1}$, and since the $1980 \mathrm{~s}$ accelerated to 4.5 days decade ${ }^{-1}$ (Kaukoranta and Hakala 2008).

In our research the flowering date of the most recent cultivar was 5 days earlier than that of the original cultivar. Phenology stages are shorter in a warmer environment allowing faster growth and earlier harvesting. However, potato is a plant that likes cooler weather and yields are influenced by summer precipitation. The higher yields in Europe are in north west and west Europe where the rainfall is higher (Supit et al. 2012). Temperature and water content control the photosynthetic process and have a substantial impact on the accumulation of dry matter (Haverkort 1990) and have a greater impact on yield than choice of cultivar (Kleinwechter et al. 2016). These same factors also have an impact on animal behaviour and performance (Maracchi et al. 2005); temperature is the most important factor controlling diapause, and humidity has an impact on post diapause development. Photoperiod has a relatively small impact on these (Kort 1990). In research on German annual and perennial crops, strong negative correlations between temperature and phenology were detected for each crop species with an average response of -4 days ${ }^{\circ} \mathrm{C}^{-1}$ (Estrella et al. 2007).

Although we used only one temperature variable (monthly average temperature), we clearly found that temperature influenced the timing and frequency of treatment against Colorado potato beetle. This is consistent with research in other countries. In Russia, Scandinavia and Northern Europe climate change has been shown to influence the distribution and the number of generations of this species (Popova 2014; Pulatov et al. 2014, 2015; Rafoss and Saethre 2003).

The life cycle of insects is controlled by environmental factors (Danks 2006). Soil temperature and accumulated heat (day degree sums) predicted the emergence date of beetles. In areas with warmer winters, Colorado potato beetle needs less accumulated heat compared to beetles from colder areas. Temperature influences both emergence dates as well as growth rates (Lehmann et al. 2015) and diapause induction of beetles is mostly controlled by photoperiod. However, diapause can by modified by temperature and food quality (Hiiesaar et al. 2016). Under warmer conditions, beetles have a reduced sensitivity to photoperiod (Hare 1990). Our results confirm the general trend of advancing phenology in both plants and insects. The consequences of the different rates of development of the plant and its enemies are not entirely clear. There is a need for further research investigating the role of this phenomenon for future potato yields and food security. Management of potato cultivation should consider changing growing conditions, temperature and rainfall. Management can be improved, for example, through proper selection of cultivars, irrigation, and modifying the planting date. Cultivars with a shorter period of development can be less vulnerable to Colorado potato beetle because the pest's appearance and activity are strongly correlated with photoperiod and temperature.

Acknowledgments The authors thank Dr. W. Waniorek and A. Knapczyk for assistance with obtaining some of the potato data.

The data used in the work has been collected in a manner consistent with the applicable law in Poland. The authors also thank three anonymous referees for valuable comments and suggestions.

Open Access This article is distributed under the terms of the Creative Commons Attribution 4.0 International License (http:// creativecommons.org/licenses/by/4.0/), which permits unrestricted use, distribution, and reproduction in any medium, provided you give appropriate credit to the original author(s) and the source, provide a link to the Creative Commons license, and indicate if changes were made.

\section{References}

Alyokhin, A., M. Baker, D. Mota-Sanchez, G. Dively, and E. Grafius. 2008. Colorado potato beetle resistance to insecticides. American Journal of Potato Research 85 (6): 395-413.

Blecharczyk, A., I. Malecka, T. Piechota, and Z. Sawinska. 2008. Wpływ następstwa roślin i nawożenia na plonowanie oraz skład chemiczny 
bulw ziemniaka odmiany Sante. Acta Scientiarum Polonorum. Agricultura 7 (3): 13-19.

Blecharczyk, A., Z. Sawinska, I. Malecka, T.H. Sparks, and P. Tryjanowski. 2016. The phenology of winter rye in Poland: an analysis of long-term experimental data. International Journal of Biometeorology 60: 1341-1346.

Danks, H.V. 2006. Key themes in the study of seasonal adaptations in insects II. Life-cycle patterns. Applied Entomology and Zoology 41: $1-13$

Dolezal, P., O. Habustova, and F. Sehnal. 2007. Effects of photoperiod and temperature on the rate of larval development, food conversion efficiency, and imaginal diapause in Leptinotarsa decemlineata. Journal of Insect Insect Physiology 53: 849-857.

Estrella, N., T.H. Sparks, and A. Menzel. 2007. Trends and temperature response in the phenology of crops in Germany. Global Change Biology 13: 1737-1747.

Gregory, P.J., S.N. Johnson, A.C. Newton, and J.S.I. Ingram. 2009. Integrating pests and pathogens into the climate change/ food security debate. Journal of Experimental Botany 60: 2827-2838.

Hack, H., H. Gall, T. Klemke, R. Klose, U. Meier, R. Stauss, and A. Witzenberger. 1993. The BBCH-scale for phenological growth stages of potato (Solanum tuberosum L.) Proceedings of the 12th annual congress of the European association for potato research, 153-154. Paris

Hare, J.D. 1990. Ecology and management of the Colorado potato beetle. Annual Review of Entomology 35: 81-100.

Harrington, R., I. Woiwod, and T. Sparks. 1999. Climate change and trophic interactions. Trends in Ecology \& Evolution 14: 146-150.

Haverkort, A.J. 1990. Ecology of potato cropping systems in relation to latitude and altitude. Agricultural Systems 32: 251-272.

Haverkort, A.J., and A. Verhagen. 2008. Climate change and its repercussions for the potato supply chain. Potato Research. 51: 223-237.

Hiiesaar, K., K. Jogar, I.H. Williams, A. Luik, E. Kruus, L. Metspalu, A. Ploomi, V. Eremeev, and M. Mänd. 2016. Phenology and overwintering of the Colorado potato beetle Leptinotarsa decemlineata Say in 2008-2015 in Estonia. Acta Agriculturae Scandinavica, Section B - Soil \& Plant Science. 66: 502-509.

Kaukoranta, T., and K. Hakala. 2008. Impact of spring warming on sowing times of cereal, potato and sugar beet in Finland. Agricultural and Food Science 17: 165-176.

Kleinwechter, U., M. Gastelo, J. Ritchie, G. Nelson, and S. Asseng. 2016. Simulating cultivar variations in potato yields for contrasting environments. Agricultural Systems 145: 51-63.

Kort, C.A.D. 1990. Thirty-five years of diapause research with the Colorado potato beetle. Entomologia Experimentalis et Applicata 56: $1-13$.

Kung, K.J.S., M. Milner, J.A. Wyman, J. Feldman, and E. Nordheim. 1992. Survival of Colorado potato beetle (Coleoptera: Chrysomelidae) after exposure to subzero thermal shocks during diapause. Journal of Economic Entomology 85: 1695-1700.

Lehmann, P., S. Piiroinen, A. Lyytinen, and L. Lindström. 2015. Response in metabolic rate to changes in temperature in diapausing Colorado potato beetle Leptinotarsa decemlineata from three European populations. Physiological Entomology 40: 123-130.

Maracchi, G., O. Sirotenko, and M. Bindi. 2005. Impacts of present and future climate variability on agriculture and forestry in the temperate regions: Europe. Climatic Change 70: 117-135.
Menzel, A., J. von Vopelius, N. Estrella, C. Schleip, and V. Dose. 2006. Farmers' annual activities are not tracking the speed of climate change. Climate Research 32: 201-207.

Parmesan, C., and G. Yohe. 2003. A globally coherent fingerprint of climate change impacts across natural systems. Nature 421: 37-42.

Peferoen, M., R. Huybrechts, and A. de Loof. 1981. Longevity and fecundity in the Colorado potato beetle, Leptinotarsa decemlineata. Entomologia Experimentalis et Applicata 29: 321-329.

Popova, E.N. 2014. The influence of climatic changes on range expansion and phenology of the Colorado Potato Beetle (Leptinotarsa decemlineata, Coleoptera, Chrysomelidae) in the Territory of Russia. Entomological Review 94: 643-653.

Porter, J.H., M.L. Parry, and T.R. Carter. 1991. The potential effects of climatic change on agricultural insects pests. Agricultural and Forest Meteorology 57: 221-240.

Pulatov, B., K. Hall, M.L. Linderson, and A.M. Jönsson. 2014. Effect of climate change on the potential spread of the Colorado potato beetle in Scandinavia: an ensemble approach. Climate Research 62: $15-24$

Pulatov, B., A.M. Jonsson, R.A.I. Wilcke, M.L. Linderson, K. Hall, and L. Barring. 2016. Evaluation of the phenological synchrony between potato crop and Colorado potato beetle under future climate in Europe. Agriculture, Ecosystem \& Environment 224: 39-49.

Pulatov, B., M.L. Linderson, K. Hall, and A.M. Jönsson. 2015. Modeling climate change impact on potato crop phenology, and risk of frost damage and heat stress in northern Europe. Agricultural and Forest Meteorology 214-215: 281-292.

Rafoss, T., and M.G. Saethre. 2003. Spatial and temporal distribution of bioclimatic potential for the Codling moth and the Colorado potato beetle in Norway: model predictions versus climate and field data from the 1990s. Agricultural and Forest Entomology 5: 75-85.

Richardson, A.D., T.F. Keenan, M. Migliavacca, Y. Ryu, O. Sonnentag, and M. Toomey. 2013. Climate change, phenology and phenological control of vegetation feedbacks to the climate system. Agricultural and Forest Entomology 169: 156-173.

Sacks, W.J., D. Deryng, J.A. Foley, and N. Ramankutty. 2010. Crop planting dates: an analysis of global patterns. Global Ecology and Biogeography 19: 607-620.

Schwartz, M.D. 1999. Advancing to full bloom: planning phenological research for the 21 st century. International Journal of Biometeorology 42: 113-118.

Sparks, T.H., P.J. Croxton, N. Collinson, and P.W. Taylor. 2005. Examples of phenological change, past and present, in UK farming. Annals of Applied Biology 146: 531-537.

Sparks, T.H., M. Górska-Zajączkowska, W. Wójtowicz, and P. Tryjanowski. 2011. Phenological changes and reduced seasonal synchrony in western Poland. International Journal of Biometeorology 55: 447-453

Supit, I., C.A. van Diepen, A.J.W. de Wit, J. Wolf, P. Kabat, B. Baruth, and F. Ludwig. 2012. Assessing climate change effects on European crop yields using the Crop Growth Monitoring System and weather generator. Agricultural and Forest Meteorology 164: 96-111.

Szajdak, L., I. Życzyńska-Bałoniak, T. Meysner, and A. Blecharczyk. 2004. Bound amino acids in humic acids from arable cropping systems. Journal of Plant Nutrition and Soil Science 167: 562-567.

Walther, G.R., E. Post, P. Convey, A. Menzel, C. Parmesan, T.J.C. Beebee, J.C. Fromentin, O. Hoegh-Guldberg, and F. Bairlein. 2002. Ecological response to recent climate change. Nature 416: 389-395. 